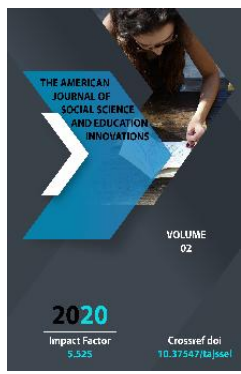

\title{
The Importance Of Spiritual Competition In Ensuring Family Cohesion
}

Abbasova M.S.

Doctoral Student Of Samarkand State University, Uzbekistan

Journal Website:

http://usajournalshub.c

om/index,php/tajssei

Copyright: Original

content from this work

may be used under the

terms of the creative

commons attributes

4.0 licence.

\section{ABSTRACT}

This article discusses the issues of spiritual importance and spiritual competition in ensuring the family integrity in the society.

\section{KEYWORDS}

Spirituality, family, social group, healthy competition, spiritual competition.

\section{INTRODUCTION}

The destruction of the family institution as the origin of the civilization of human society is associated with the formation of the family institution can bring about the destruction of the civilization of mankind. Therefore, today there is also a global crisis in the family, among the problems that cast doubt on the next existence of human beings. The problem of the family crisis has cast doubt on the next existence of humanity, just like the threat of nuclear weapons of destruction, the threat of terrorism and the environmental threat, and they are all connected with the impoverishment of spirituality on a global 
scale. In this regard, we must rely on the concept of meaningful competition. The mutual nature of those that compete spiritually is the formation of a enlightened ideological view, which consists in making morality or immorality, or nobility of ignorance, or nobility, in order to find solutions to the problems of setting goals from which society lives to understand and understand the processes that are taking place in human thinking. Because spirituality is the force that motivates a person to live with himself in a stupor, and this force ensures that a person is able to live with himself in a stupor before nature, before society and before man. The family has ensured the continuity of life, which for thousands of years is the content of life. But to this day, the fulfillment of one's own function in the family is a problem, because, as a result of spiritual poverty, a person forgot to restrain himself before the family. Failure to perform family function may lead to the depopulation process at the level of human coldness.

\section{MATERIALS AND METHODS}

We can say that the problem of the family is the most urgent and most difficult problem that is thought of humanity today. President Of The Republic Of Uzbekistan M. Mirziyoyev spoke about the strengthening of the Family Institute" in the strategy of actions for the development of Uzbekistan in 2017-2021 " and defined the development and implementation of comprehensive measures for the further strengthening of the family foundations and further improvement of the family as a priority task. This problem is thought-provoking sociologist scientists, but not everyone. Therefore, we are trying to analyze the problem of the global crisis of the family below and try to find the reasons for this problem and find ways to overcome them.
With this, we can achieve the strengthening of the family and increasing the responsibility of the parents, because the decline in the responsibility of the parents before the family is associated with the crisis of the family institution.

The scientific hypothesis of the study is that in the process of Social Development, insufficient attention has been paid to the family institution and the spiritual upsurge has been caused by the crisis of the family institution, and today the withdrawal of the family institution from the crisis is the most important factor in the connection with the strong social policy Care plays an important role in the removal of the family from the crisis, strengthening and increasing the responsibility of parents before the upbringing of the child. Therefore, in strengthening the family and increasing the responsibility of parents, the need arises to ensure the development of the education and upbringing system in harmony, especially raising morale. That is, the satisfaction of the needs arising on the basis of this need, that is, the implementation of a social policy aimed at the family, and the spiritual upsurge, are important in strengthening the family.

Before we talk about the problem of the family, we need to give a clear definition of what the family is, that is, what it is and show it its main functions. Sociologist scientists give the family such a definition: the family is formed on the basis of marriage, a group of people connected with the bonds of couple, motherhood and caricature, and it performs the functions of bringing the child into the world, bringing him to life and preparing him for life. So it turns out that in order for the family to be a full-fledged family, it must fulfill the integrity of the three elements and the three main functions. If there is no one of 
these three elements of the family and does not perform one of the three main functions, then this is a sign of the family's incises. Socialization of the child is carried out mainly in the family, so the main attention should be paid to the Family Institute. Speaking in this regard, the specialists said that "the child is 34 years before going to the pre-school educational institution, while being involved in education, for a full 2 days a week, that is, on Saturdays, on Sundays, on other days 24 hours a day spends 15-16 hours at home. During this period, in the apartment, he tries to assimilate all of them, no matter what kind of behavior, Gossip, gestures someone has. Each of them takes a template from their actions and sayings".

\section{RESULTS AND DISCUSSIONS}

So what are the symptoms of family incontinence? Today, non-matrimonial families are becoming more and more, vaholanki, the family should be formed on the basis of marriage. Therefore, we can say that the emergence of non-marriages is a manifestation of a family crisis. Divorce in the family occurs more often, when families with one child or without children appear, even when same-sex marriages occur gays and lesbians. All this shows that today the family is experiencing a crisis from its very beginning. It is true that the global crisis of the right family is manifested more strongly in Western countries, and in us it is manifested in the end. But we do not have to be calm that the family crisis is within reach of us much further, because in a globalized world, the family crisis is easily penetrated in all countries. Therefore, all the qualifications of the world must be fought against the family incubation in their own territory. To do this, it is necessary first of all to try to find the causes of the family crisis.
It can be said that the cause of family incontinence is in the pouring of forgetting about the immobility of the family and the overgrowth of egoism in people. And the reason for this is the connection with the pioneering of spirituality on a global scale. In general, all the problems that exist today are ultimately tied to spirituality. Because in order for a person to avoid responsibility before the family and to slip in family childbirth, he must be able to restrain himself in front of the family. In other words, a person must restrain his interests before the benefit of the family, put the interests of the family above his personal interest. For this, however, one must have a holiness over oneself, and such holiness is provided by spirituality, because spirituality gives a person the opportunity to behave before the family.

In order to get the family out of the crisis and to consolidate it, a person must realize that the family is a mogul. Why the family is called holy? The family is therefore called holy because the family represents the content of life. The essence of life is to ensure the continuity of human life, and its maintenance is carried out through the family. Human beings are not eternal beings when it has appeared and the subsequent existence of it has become a link to the family. The family is such a unique evolutionary invention of mankind that it has been providing humanity with the next existence for thousands of years, but today it is suspected that the family will fulfill its functions and ensure that humanity will exist tomorrow.

The main emphasis in Family Development should be placed on the formation of a serious attitude to Marriage, since Marriage is the formation of responsibility before the family in a person. Marriage also has an important role to play on the basis of modern deposits and 
Sharia ones. If the state registration on the basis of modern laws forms responsibility before the state in man, while the passage of marriage on the basis of Sharia law forms responsibility before God. Man is such a being that he must be able to walk along the path and see something, including in order to keep himself standing in front of the benefit of the family. A person should be seen from the state so that he does not violate the laws of the Times, and he should be afraid of the torment of the hereafter, so as not to violate the laws of Sharia. The family is such a unique evolutionary discovery that it is possible to use both the laws of the Times and the laws of Sharia to preserve vigorously. The destruction of the Family Institute without any exaggeration can bring about the destruction of human civilization.

In the family consolidation, it is important that the couple, which is the basis of the family, be firm, because the couple is the core of the family. The more independent the core, the more the family is the stronger. To do this, that is, the core, which is the basis of the family, should be strong; the couple should understand each other. When they say what they need to understand, it can be said that one of them must understand that happiness is associated with the happiness of the other. Realizing this, the couple will be able to overcome the difficulties who will survive. And the couple who do not understand it on the contrary can break up a holy thing as a family without being able to overcome a problem at all. Therefore, in order to strengthen the family, it is necessary to pay attention to increasing the responsibility of the couple in front of the family and to strengthen it.,

In order for the responsibility to be strong before the family, a person must know a simple fact that with the structure of marriage, a person is deprived of the right to think only of himself, now they have to think of each other. And with the birth of a child in the family, the couple must realize that they are no longer deprived of the right to think for themselves, because now they will have to restrain themselves in the interests of the child. As the child is the successor of their offspring, that is, the content of their lives. Parents should not forget that by caring for a child and preparing him for life, he has created the conditions for old age. To do this, man must know another simple truth that man's happiness depends first and foremost on the family, and that as long as there is a human race, he must be protected within the family until he is born and leaves the world. Only the institution of the family can serve the human race gratefully and ensure its happiness. The institution of the family has been fulfilling its function for thousands of years to ensure the subsequent existence of humanity, but today it remains a problem.

Another reason for the crisis of the family is related to the staffing of women in this family. In the course of a long historical process, the woman gradually began to be involved in social activities outside the family, and at the same time the role of the woman in the family remained on her shoulders. As a result, a woman begins to work in the family and in social life, and in the process, a woman's work in the family is neglected. As a result, a woman's responsibility to the family begins to decline and negatively affects the strength of the family. However, a family cannot be imagined without a woman and her cocktail, because nature has created a family in such a way that a woman plays a key role in it.

Therefore, today it is necessary to further strengthen the role and position of a woman in the family in order to bring the family out of 
the crisis and to consolidate it. In other words, it is necessary for a woman to agree that the housewife in the family is not an unemployed, idler, but the most necessary and most honorable profession. Opening a cocktail notebook for a home cocktail to a woman should be viewed as the most desired and honorable profession of Labor fare her if necessary. In the family, a person both satisfies his personal excesses, and the excesses of the state and society to the owners of a certain status and role. We must not forget about the simple betrayal realized by the developed countries of the world, that is, the fact that the wealth of the country is formed from the wealth of a noble family. The declaration of 2017 by the distinguished president of our country Shavkat Mirziyoyev as the year of dialogue with the people and human interests clearly shows that the problems of social protection in our country are the priority tasks of the state social policy. In the year of dialogue with the people and human interests is characterized by the fact that the main focus is on strengthening the family institution.

In family consolidation, it is important that the health level of the environment in the family is recognized as the main criterion in the system of Personnel Selection. With this, we achieve not only the strengthening of the family, but also the selection of worthy personnel. As a person who is able to establish a healthy environment in his family will be able to establish order even in a single team. In order for a person to establish order in his family, he must first establish order in himself, and such a procedure depends on the authority of the person over himself. In order for man to have power over himself, he must have high spirituality in him because spirituality forms the authority that man has over himself. A person who has authority over himself will have a strong responsibility before the family and the upbringing of the child. Therefore, compliance with this criterion serves to increase the responsibility of parents before the family. Not only in the system of Personnel Selection, but also in the incentive system and in the judicial system, should the level of health of the family environment be the main criterion when is a person evaluated. In general, a person's environment in the family should be the main criterion that determines his reputation in society. In the system of Personnel Selection, promotion and judicial system, the use of the criterion in the family as the main criterion that determines the fate of a person is important in increasing the parental responsibility before the family and child upbringing.

\section{CONCLUSION}

In conclusion, it should be noted that the further strengthening of the family by removing it from the current crisis situation and increasing the parental responsibility for the upbringing of the family and the child depend on raising the morale of the society. In addition, in order to strengthen the family, it is necessary, first of all, to understand the family institution as a criterion, to further enhance and appreciate the role of a woman in the family, to recognize the level of healthiness of the environment in the family as the main criterion for assessing a person, and to create all the conditions necessary for the Family consolidation should be considered as the most important and urgent task of the state and society in partnership. The goal would be to improve the way of socially oriented market relations implemented in our country as a way of socially oriented market relations in relation to the family. Because the Institute of the family is such a unique evolutionary discovery of mankind that it has ensured the 
next existence of the human race on the basis of internal motivations for thousands of years, and today it remains a problem. To express the meaning of the issue of removing and strengthening the family institution from the crisis is today considered being the most urgent and most difficult problem both for the state and for society. To solve this problem, the family institution should be regarded as an object of support of the state and society on the basis of social partnership. Only on the basis of social partnership it is possible to take the family institution out of the crisis and further strengthen it, ensuring the continuity of life in which there is a meaning.

\section{REFERENCES}

1. Mirziyoev.Sh.M. Strategy of actions. Tashkent. 2017, p.4

2. Buronov.M. Evolutionary development of spiritual enlightenment policy in Uzbekistan .Tashkent. 2016, p.140

3. Mirziyoev Sh.M. The Speech dedicated on the 24th anniversary of the Constitution of the Republic of Uzbekistan. Tashkent. 2016, 8 December.

4. Muhamadjonovna, S. D. (2020). The key concepts of forming sociolinguistic competence of future English language specialists. Asian Journal of Multidimensional Research (AJMR), 9(5), 118-121.

5. Muhamadjonovna, S. D. (2020). The development of sociolinguistic competence of future English language teachers through computer technologies. 